\title{
Perubahan Komposisi Batuan Metamorf Akibat Proses Alterasi Hidrotermal pada Endapan Emas di Pegunungan Rumbia, Pada Lengan Tenggara Pulau Sulawesi
}

\section{Changes in Metamorphic Rock Composition Due to Hydrothermal Alteration Process in Gold Deposits at the Rumbia Mountains, in the Southeast Arm of Sulawesi Island}

\author{
Hasria $^{1}$, Arifudin Idrus ${ }^{2}$, I Wayan Warmada ${ }^{2}$ \\ ${ }^{1} J u r u s a n$ Teknik Geologi, Universitas Halu Oleo, Kendari \\ ${ }^{2}$ Departemen Teknik Geologi, Universitas Gadjah Mada, Yogyakarta \\ email: hasriageologi@gmail.com
}

Naskah diterima : 16 Agustus 2019, Revisi terakhir : 11 Agustus 2020 Disetujui : 12 Agustus 2020, Online : 12 Agustus 2020

DOI: http://dx.doi.org/10.33332/jgsm.geologi.21.3.119-127p

\begin{abstract}
Abstrak-Pada proses alterasi hidrotermal, reaksi batuan samping dengan fluida hidrotermal yang melewatinya akan menyebabkan perubahan komposisi (oksida/unsur) pada batuan yang dilewati maupun pada fluida itu sendiri. Perhitungan perubahan oksida/unsur bertujuan untuk menentukan oksida/unsur dalam batuan yang bertambah atau berkurang karena proses alterasi hidrotemal, dilakukan dengan menggunakan analisis ICP-AES (Inductively Coupled Plasma Atomic Emission Spectroscopy) dan ICP-MS (Inductively Coupled Plasma Mass Spectrometry). Hasil penelitian menunjukkan bahwa oksida/unsur yang immobile umumnya relatif tidak mengalami perubahan komposisi selama proses alterasi hidrotermal berlangsung, sedangkan oksida/unsur mobile umumnya mengalami penambahan dan pengurangan selama proses alterasi hidrotermal berlangsung. Pada alterasi propilitik, oksida/unsur mobile yang mengalami penambahan adalah $\mathrm{As}, \mathrm{Zr}, \mathrm{Cu}, \mathrm{Sb}, \mathrm{Ca}, \mathrm{CaO}, \mathrm{MgO}, \mathrm{MnO}$ dan $\mathrm{SiO}_{2}$ dan yang mengalami pengurangan adalah $\mathrm{U}, \mathrm{Th}, \mathrm{Co}, \mathrm{Sn}, \mathrm{Sr}$, $\mathrm{Nb}, \mathrm{Ba}, \mathrm{K}, \mathrm{Au}, \mathrm{Pb}, \mathrm{Zn}, \mathrm{V}, \mathrm{Fe}, \mathrm{K}_{2} \mathrm{O}, \mathrm{Na}_{2} \mathrm{O}$ dan $\mathrm{Fe}_{2} \mathrm{O}_{3}$. Pada alterasi serisitik, oksida/unsur mobile yang mengalami penambahan adalah $\mathrm{Sb}, \mathrm{Zr}, \mathrm{Ag}, \mathrm{Pb}, \mathrm{K}, \mathrm{Na}_{2} \mathrm{O}, \mathrm{SiO}_{2}$ dan yang mengalami pengurangan adalah $\mathrm{U}, \mathrm{Th}, \mathrm{Co}, \mathrm{As}, \mathrm{Nb}$, $\mathrm{Ba}, \mathrm{Sn}, \mathrm{Sr}, \mathrm{Ca}, \mathrm{S}, \mathrm{Au}, \mathrm{V}, \mathrm{Zn}, \mathrm{Cu}, \mathrm{Fe}, \mathrm{K}_{2} \mathrm{O}, \mathrm{MnO}, \mathrm{CaO}$, $\mathrm{MgO}, \mathrm{Fe}_{2} \mathrm{O}_{3}$. Pada alterasi argilik, oksida/unsur mobile yang mengalami penambahan adalah $\mathrm{Sb}, \mathrm{Fe}, \mathrm{S}, \mathrm{Cu}, \mathrm{Zr}$, $\mathrm{Ba}, \mathrm{As}, \mathrm{Au}, \mathrm{Zn}, \mathrm{V}$, dan $\mathrm{SiO}_{2}$ sedangkan yang cenderung mengalami pengurangan adalah $\mathrm{Ca}, \mathrm{U}, \mathrm{Th}, \mathrm{Nb}, \mathrm{Sn}, \mathrm{Sr}$, $\mathrm{Co}, \mathrm{Pb}, \mathrm{K}, \mathrm{CaO}, \mathrm{Na}_{2} \mathrm{O}, \mathrm{MnO}, \mathrm{MgO}, \mathrm{K}_{2} \mathrm{O}$ dan $\mathrm{Fe}_{2} \mathrm{O}_{3}$.
\end{abstract}

\begin{abstract}
In the hydrothermal alteration process, wall rock reaction with hydrothermal fluid that passes through it will cause changes the composition (oxides/elements) both in the wall rock and the fluid itself. The oxides/elements changing calculation aims to determine the oxides/elements in the rock that are enriched or depleted as a result of hydrotemal alteration processes using ICP-AES (Inductively Coupled Plasma Atomic Emission Spectroscopy) and ICP-MS (Inductively Coupled Plasma Mass Spectrometry). The results showed that immobile oxides/elements were generally relatively unchanged during the hydrothermal alteration process while oxides/elements mobile generally experienced enriched and depleted during the hydothermal alteration processes. In propylitic alteration, the mobile oxides/elements that have been enriched are $\mathrm{As}, \mathrm{Zr}, \mathrm{Cu}, \mathrm{Sb}, \mathrm{Ca}, \mathrm{CaO}, \mathrm{MgO}, \mathrm{MnO}$ and $\mathrm{SiO}_{2}$, and depleted are $\mathrm{U}, \mathrm{Th}, \mathrm{Co}, \mathrm{Sn}, \mathrm{Sr}, \mathrm{Nb}, \mathrm{Ba}, \mathrm{K}, \mathrm{Au}, \mathrm{Pb}$, $\mathrm{Zn}, \mathrm{V}, \mathrm{Fe}, \mathrm{K}_{2} \mathrm{O}, \mathrm{Na}_{2} \mathrm{O}$ and $\mathrm{Fe}_{2} \mathrm{O}_{3}$. In sericitic alteration, the mobile oxides/elements are enriched are $\mathrm{Sb}, \mathrm{Zr}, \mathrm{Ag}, \mathrm{Pb}, \mathrm{K}$, $\mathrm{Na}_{2} \mathrm{O}, \mathrm{SiO}_{2}$ and depleted are $\mathrm{U}, \mathrm{Th}, \mathrm{Co}, \mathrm{As}, \mathrm{Nb}, \mathrm{Ba}, \mathrm{Sn}, \mathrm{Sr}$, $\mathrm{Ca}, \mathrm{S}, \mathrm{Au}, \mathrm{V}, \mathrm{Zn}, \mathrm{Cu}, \mathrm{Fe}, \mathrm{K}_{2} \mathrm{O}, \mathrm{MnO}, \mathrm{CaO}, \mathrm{MgO}, \mathrm{Fe}_{2} \mathrm{O}_{3}$. In argillic alteration, the mobile oxides/elements enriched are $\mathrm{Sb}, \mathrm{Fe}, \mathrm{S}, \mathrm{Cu}, \mathrm{Zr}, \mathrm{Ba}, \mathrm{As}, \mathrm{Au}, \mathrm{Zn}, \mathrm{V}$, and $\mathrm{SiO}_{2}$ and depleted are $\mathrm{Ca}, \mathrm{U}, \mathrm{Th}, \mathrm{Nb}, \mathrm{Sn}, \mathrm{Sr}$, $\mathrm{Co}, \mathrm{Pb}, \mathrm{K}, \mathrm{CaO}, \mathrm{Na}_{2} \mathrm{O}, \mathrm{MnO}, \mathrm{MgO}$, $\mathrm{K}_{2} \mathrm{O}$ and $\mathrm{Fe}_{2} \mathrm{O}_{3}$.
\end{abstract}

Keyword : hydrothermal alteration, Rumbia Mountains, Bombana Regency, change of oxides/elemnets, mobile, immobile.

Katakunci : Alterasi hidrotermal, Pegunungan Rumbia,

Kabupaten Bombana, perubahan oksida/unsur, mobile, immobile. 


\section{PENDAHULUAN}

Alterasi hidrotermal merupakan suatu proses yang sangat kompleks, meliputi perubahan mineral, kimia dan tekstur yang terjadi karena adanya interaksi larutan (fluida) panas dengan batuan yang dilewatinya pada kondisi fisika-kimia tertentu. Alterasi terjadi karena kumpulan mineral pada batuan samping (wall rocks) tidak stabil terhadap kehadiran larutan hidrotermal dan cenderung untuk mencapai keadaan kesetimbangan (re-equilibrate) kembali dengan membentuk kumpulan mineral-mineral baru yang stabil pada kondisi yang baru tersebut.

Bentuk-bentuk cebakan hidrotermal sering mengikuti bentuk rongga atau rekahan yang diisinya, kadangkadang diikuti oleh proses replacement. Pada cebakan cavity filling bisa terjadi dua proses, yaitu pembentukan rongga dan pengisian larutan mineral. Proses tersebut bisa terjadi bersamaan atau dipisahkan oleh interval waktu. Dalam proses hidrotermal sering terdapat mineral-mineral ubahan yang terbentuk akibat endapan bijih hidrotermal karena sirkulasi fluida hidrotermal yang melindi (leaching), menstransport, dan mengendapkan mineral-mineral baru sebagai respon terhadap perubahan kondisi fisik maupun kimiawi (Prijanno, 2009). Oleh karena itu, komposisi kimia fluida hidrotermal diyakini sebagai salah pengontrol utama pada proses alterasi. Alterasi hidrotermal sangat penting pada eksplorasi mineral, karena alterasi ini dapat digunakan sebagai petunjuk batas kehadiran bijih sehingga target eksplorasi dapat dipersempit dari suatu area yang luas. Faktor-faktor utama yang mengontrol proses alterasi meliputi: jenis batuan samping, temperatur, komposisi fluida, konsentrasi, aktifitas dan potensial kimia unsur-unsur fluida, seperti $\mathrm{H}^{+}, \mathrm{CO}_{2}, \mathrm{O}_{2}, \mathrm{~K}^{+}$, dan $\mathrm{SO}_{2}$ (Prijano, 2009).

Pada proses alterasi hidrotermal, reaksi antara fluida hidrotermal dengan batuan-batuan samping yang dilewatinya akan mengakibatkan perubahan komposisi fluida maupun batuan yang melewatinya. Secagai akibatnya akan terjadi pengurangan atau penambahan komponen (oksida/unsur) tertentu. Olehnya itu, penting dilakukan suatu perhitungan yang bertujuan untuk mengkalkulasi keseimbangan komponen unsur-unsur dalam batuan yang telah hilang maupun bertambah karena proses alterasi hidrotermal tersebut.

Kalkulasi ini bertujuan untuk menghitung perubahan kandungan unsur-unsur mobile pada batuan yang mengalami ubahan komposisi terhadap kandungan unsur pada batuan precursor-nya dengan menggunakan acuan unsur-unsur yang immobile. Oksida/unsur yang dianggap immobile adalah oksida/unsur yang relatif tidak mengalami perubahan komposisi selama proses alterasi hidrotermal berlangsung.
Penambahan dan pengurangan oksida/unsur karena proses hidrotermal pertama kali dilakukan oleh Gresen (1967) dengan sebuah persamaan linier yang menggambarkan hubungan antara konsentrasi komponen tertentu dalam batuan teralterasi dengan batuan aslinya. Persamaan ini kemudian direvisi oleh Grant (1986), yang memperkenalkan diagram isokon untuk menggambarkan keseimbangan oksida/unsur. Garis isokon merupakan garis yang menghubungkan titik-titik yang ditunjukkan oleh semua komponen yang relatif tidak memperlihatkan penambahan atau pengurangan konsentrasi. Gradien isokon dibentuk dari massa sampel batuan segar (fresh rocks) atau sampel yang sedikit mengalami ubahan (least altered) berbanding dengan sampel yang telah terubah (altered rocks; Mo/Ma). Oksida/unsur yang diplot di atas garis isokon adalah oksida/unsur yang telah mengalami peningkatan/penambahan selama proses alterasi, sedangkan unsur yang diplot di bawah garis isokon adalah unsur yang telah mengalami pengurangan selama proses alterasi, dan oksida/unsur yang relatif berada pada garis isokon merupakan oksida/unsur yang relatif immobile.

Grant (2005) kembali merevisi metode sebelumnya dari Gresens (1967) dan Grant (1986), dan menuliskan kembali dalam bentuk persamaan :

$$
\begin{array}{ll}
\mathrm{CAi} & =\mathrm{MO} / \mathrm{MA}\left(\mathrm{C}^{\mathrm{O}} \mathrm{i}+? \mathrm{Ci}\right), \text { dalam hal ini } \\
\mathrm{Ci} & =\text { konsentrasi ke- } \mathrm{i} \\
\mathrm{O} & =\text { sampel batuan orginal/batuan segar } \\
\mathrm{A} & =\text { sampel batuan teralterasi }
\end{array}
$$

MO/MA = perbandingan massa batuan segar dengan batuan teralterasi

? $\mathrm{Ci}=$ perubahan konsentrasi (bertambah/berkurang) dari ke- $1\left(\mathrm{C}^{\mathrm{A}}-\mathrm{C}^{\mathrm{O}}\right)$

$\mathrm{CAi} / \mathrm{COi}=$ slope atau rasio konsentrasi unsur pada batuan yang terubah dan batuan original.

Penelitian ini berlokasi di Pegunungan Rumbia, Kabupaten Bombana, Provinsi Sulawesi Tenggara (Gambar 1). Daerah penelitian merupakan bagian dari Lengan Tenggara Sulawesi, yang secara stratigrafi terdiri atas Molase Sulawesi, Kompleks Ofiolit dan Kompleks Batuan Metamorf (Surono, 2013).

Batuan metamorf di daerah penelitian termasuk dalam Kompleks Pompangeo (Simandjuntak dkk., 1993). Batuan metamorf di daerah penelitian umumnya terdiri atas sekis mika, sekis klorit, filit, sekis genesan, sekis kalsit, sekis aktinolit, sekis grafitsekis amfibolit, sekis genesan dan batugamping meta (Permana, 2013) dan (Hasria dkk., 2017). 


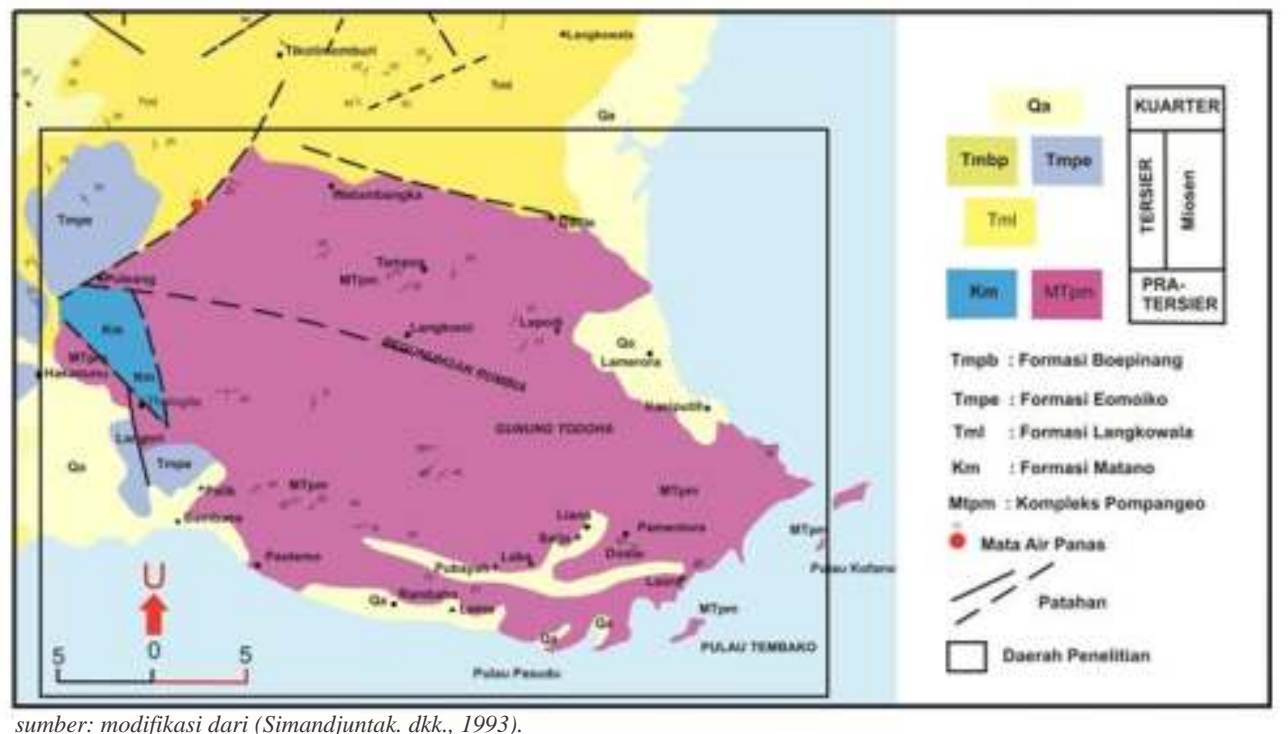

Gambar 1. Peta geologi Pegunungan Rumbia, Kabupaten Bombana, Sulawesi Tenggara.

\section{METODE PENELITIAN}

Metode penelitian dibagi dalam 3 (tiga) tahap yakni: (1) studi pustaka (desk study), (2) pekerjaan lapangan (fieldwork) dan (3) analisis laboratorium.

Pada tahap ini dilakukan pengumpulan data sekunder dan pengkajian literatur hasil penelitian terdahulu yang berhubungan dengan kondisi geologi daerah penelitian.

Pekerjaan lapangan meliputi pengamatan geologi permukaan dan zona alterasi serta pengambilan sampel yang representatif yang meliputi batuan segar dan batuan teralterasi pembawa emas.

Analisis laboratorium pada penelitian ini terdiri atas analisis ICP-AES (Inductively Coupled Plasma Atomic Emission Spectroscopy) dan ICP-MS (Inductively Coupled Plasma Mass Spectrometry). Analisis ICP-AES bertujuan untuk mendeterminasi oksida utama (major elements), unsur minor dan LOI (Loss on Ignition) pada sampel batuan (ALS Geochemistry Canada, 2016). Analisis ICP-MS bertujuan untuk menganalisis komposisi kimia yang meliputi unsur-unsur jejak dan REE pada sampel batuan. Analisis ICP-AES dan ICP-MS dilakukan di Laboratorium ALS Canada Ltd. di Canada dan jumlah sampel yang dianalisis sebanyak 12 sampel, dengan litologi yang sama yakni batuan metamorf sekis klorit. Batuan sekis klorit di lapangan cukup melimpah dan hadir pada setiap alterasi batuan. Preparasi sampel pada metode ini menggunakan Lithium Metaborate/Lithium Tetraborate $\left(\mathrm{LiBO}_{2} / \mathrm{Li}_{2} \mathrm{~B}_{4} \mathrm{O}_{7}\right)$. Dasar pengambilan sampel untuk analisis ICP-AES dan ICP-MS adalah sampel yang telah dilakukan analisis petrografi (Hasria dkk., 2019). Dengan demikian, analisis ini merupakan kelanjutan dari analisis petrografi untuk mengetahui oksida/unsur yang bertambah/berkurang akibat proses alterasi hidrotermal berdasarkan persamaan Grant (2005). Dalam perhitungan oksida/unsur yang bertambah/berkurang, harus menggunakan sampel batuan yang terubah (altered rocks) serta batuan segar yang tidak terubah atau sedikit mengalami ubahan (unaltered rocks atau least altered rocks), atau dengan batuan terubah tetapi sebagai precursor. Perhitungan perubahan komposisi ini menggunakan batuan least altered dan batuan yang teralterasi yang berasal dari satu jenis batuan yang sama (single precursor), karena akan sangat rumit jika menggunakan batuan alterasi yang berasal dari batuan banyak jenis (multiple precursor). Sampel yang digunakan pada penelitian ini adalah batuan metamorf sekis klorit.

\section{HASIL DAN PEMBAHASAN}

Penentuan dalam penambahan/pengurangan oksida/unsur yang disebabkan oleh alterasi hidrotermal didasarkan pada jenis alterasi batuan oleh Hasri dkk. (2019a), bahwa di Pegunungan Rumbia terdapat 3 (tiga) jenis alterasi batuan yakni alterasi propilitik, serisitik dan alterasi argilik (Gambar 2). 

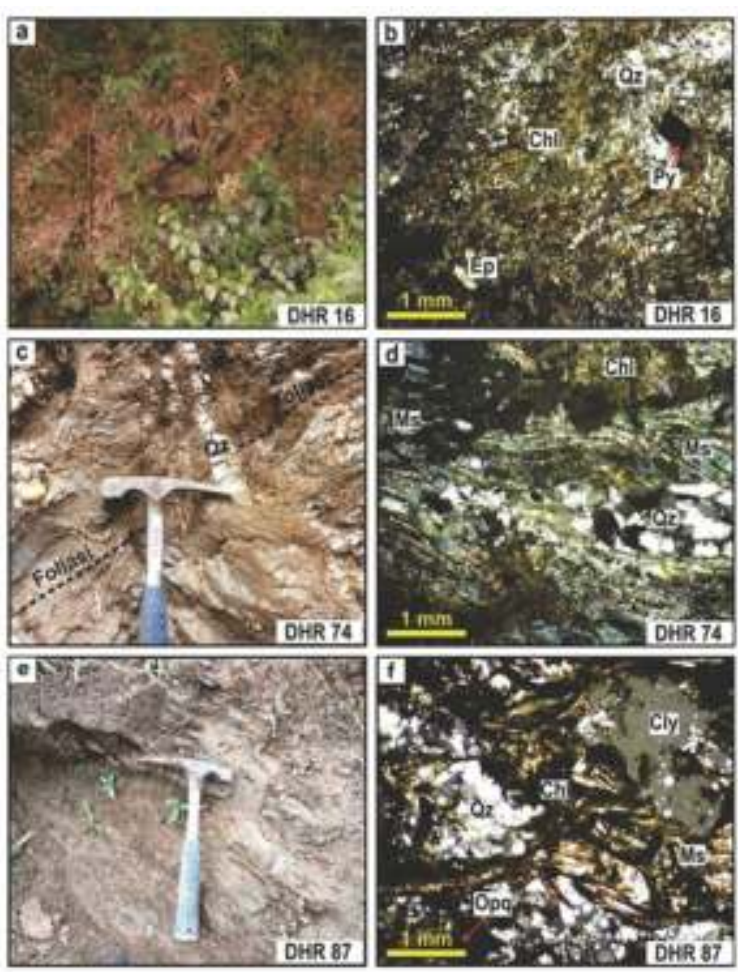

Gambar 2. Alterasi hidrotermal di daerah penelitian. a Singkapan alterasi propilitik; b. Fotomikrografi pada sayatan tipis yang memperlihatkan himpunan mineral propilitik; c. Singkapan alterasi serisitik; d. fotomikrografi pada sayatan tipis yang memperlihatkan himpunan mineral serisitik e. Singkapan alterasi argilik; f. Fotomikrografi pada sayatan tipis yang memperlihatkan himpunan mineral argilik. Chl=klorit, $\mathrm{Py}=$ pirit, Opq=opak, Qz=kuarsa, Ep=epidot, Cly=clay, Ms=muskovit.

\section{Perubahan Komposisi Oksida/Unsur pada Alterasi Propilitik}

Alterasi propilitik dicirikan oleh kehadiran mineral epidot dan atau klorit, kalsit serta mineral lain seperti mineral opak dan kuarsa. Oksida/unsur yang cenderung immobile pada alterasi ini adalah $\mathrm{Hf}, \mathrm{Lu}$, $\mathrm{Yb}, \mathrm{Tm}, \mathrm{Ho}, \mathrm{Tb}, \mathrm{Er}$ dan $\mathrm{TiO}_{2}$ (Gambar 3). Oksida/unsur yang mengalami penambahan adalah As, $\mathrm{S}, \mathrm{Zr}, \mathrm{Cu}, \mathrm{Sb}, \mathrm{Ca}, \mathrm{CaO}, \mathrm{MgO}, \mathrm{MnO}$ dan $\mathrm{SiO}_{2}$ dan oksida/unsur yang mengalami pengurangan adalah $\mathrm{U}$, Th, Co, Sn, Sr, Nb, Ba, K, Au, Pb, Zn, V, Fe, $\mathrm{K}_{2} \mathrm{O}$, $\mathrm{Na}_{2} \mathrm{O}$ dan $\mathrm{Fe}_{2} \mathrm{O}_{3}$ (Tabel 1). Pada alterasi ini, terjadinya penambahan pada oksida $\mathrm{CaO}$, diindikasikan disebabkan oleh plagioklas yang belum semuanya berubah menjadi serisit. Peningkatan unsur $\mathrm{Ca}$ diinterpretasikan akibat keberadaan mineral kalsit yang menggantikan plagioklas, juga disebabkan oleh larutan hidrotermal yang banyak mengandung $\mathrm{Ca}$, $\mathrm{H}_{2} \mathrm{O}$ dan $\mathrm{CO}_{2}$ serta sedikit $\mathrm{H}^{+}$. Kehadiran mineral kalsit dan klorit menunjukan bahwa $\mathrm{pH}$ fluida mendekati netral. Pengendapan kalsit dan epidot berhubungan erat dengan fluktuasi konsentrasi $\mathrm{CO}_{2}$ dalam fluida hidrotermal pada $\mathrm{pH}$ mendekati netral, dimana pembentukan mineral kalsit terbentuk seiring dengan peningkatan konsentrasi $\mathrm{CO}_{2}$ dan berkurangnya stabilitas epidot. Penurunan konsentrasi oksida $\mathrm{Na}_{2} \mathrm{O}$, $\mathrm{K}_{2} \mathrm{O}$ dan unsur $\mathrm{Sr}$ disebabkan oleh perusakan (breakdown) mineral plagioklas dalam batuan serta ketidakhadiran biotit sekunder. Penambahan pada oksida $\mathrm{SiO}_{2}$ walaupun tidak signifikan menunjukkan bahwa proses pembentukan urat-urat kuarsa pada alterasi ini sudah mulai berkembang. Berdasarkan kehadiran himpunan mineral klorit, epidot, dan kalsit, maka kisaran temperatur pembentukan alterasi ini sekitar $250-300^{\circ} \mathrm{C}$ (Hedenquist dkk., 2000; Corbett dan Leach, 1997). Sebaran alterasi ini umumnya lebih besar, akan tetapi kaitannya secara langsung dengan mineralisasi emas di daerah penelitian sangat kecil (Gambar 5).

Pada alterasi ini, unsur Au mengalami pengurangan karena merupakan tahapan awal pembentukan endapan emas dan belum mengalami pengayaan. Bertambahnya unsur $\mathrm{Sb}$ dan As kemungkinan berhubungan dengan kehadiran minor mineral stibnit dan Arsen yang bersesuaian dengan kadar mineral bijih (Hasria dkk, 2017; Hasria dkk., 2019a).

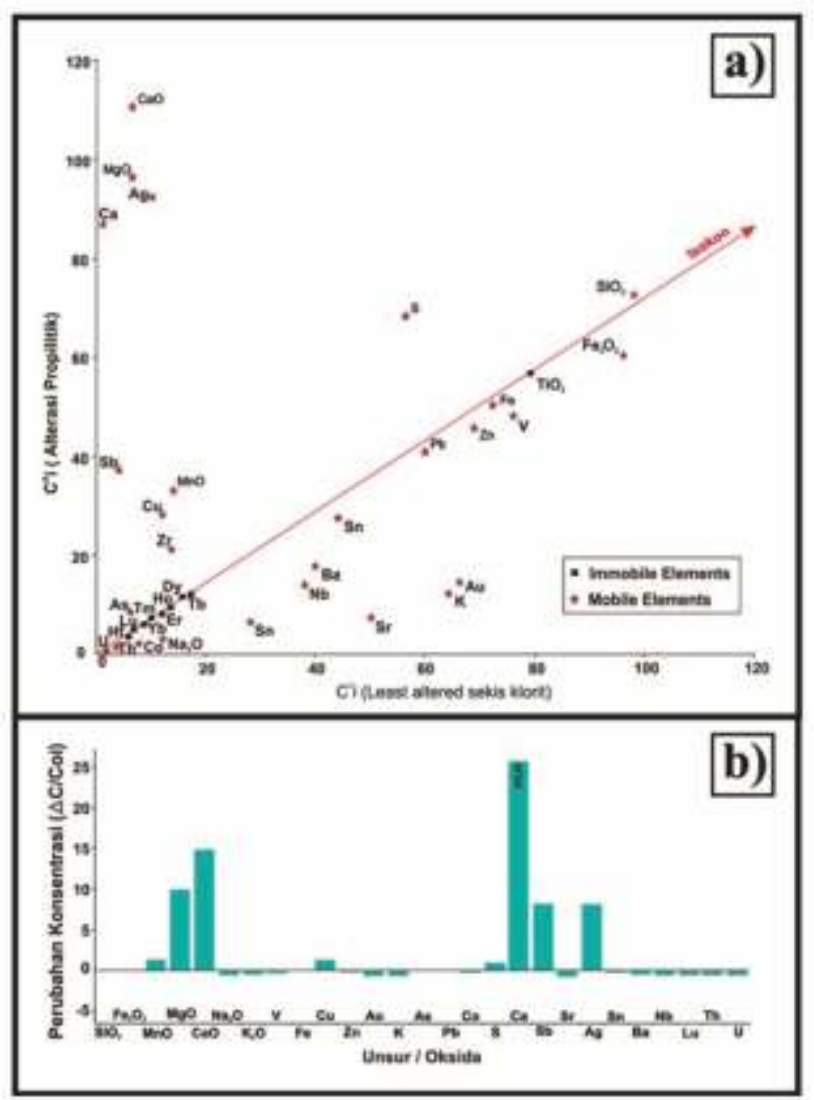

G ambar 3. Ploting antara least altered dengan alterasi propilitik batuan sekis klorit. a). diagram isokon, b). perubahan konsentrasi (? C/ Coi) antara least altered dan alterasi propilitik pada batuan sekis klorit. Oksida dan unsur $\mathrm{Ca}$, $\mathrm{Fe}, \mathrm{K}$ dan Sdalam wt. \% dan unsur lainnya dalamppm. 
Tabel 1. Analisis isokon pada alterasi propilitik Pegunungan Rumbia

\begin{tabular}{|c|c|c|c|c|c|}
\hline $\begin{array}{l}\text { Unes: } \\
\text { ekilat }\end{array}$ & $\begin{array}{c}\text { Sanpel } \\
\text { least } \\
\text { atered }\end{array}$ & $\begin{array}{l}\text { Rernes } \\
\text { sarpel } \\
\text { batea } \\
\text { tetzlierad }\end{array}$ & $\begin{array}{c}\text { slepe an: } \\
\text { tata }\end{array}$ & 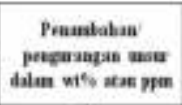 & 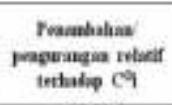 \\
\hline & C9 & $\mathrm{CH}^{4}$ & $\mathrm{CH}^{4} \mathrm{C}$ & $\triangle 0$ & 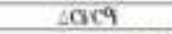 \\
\hline $500_{4}$ & 50 & 522 & 1.64 & 22 & 0.044 \\
\hline $\mathrm{F}=\mathrm{O}_{3}$ & 9.29 & 8.45 & 6.876729 & 4.45 & -0.1238 \\
\hline $\mathrm{M}+0$ & 0.14 & 0.33 & 2.35714 & 0.19 & 1.35714 \\
\hline MeO & 1.99 & 15.7 & 110651 & 17.01 & 100551 \\
\hline $\mathrm{COO}_{0}$ & 0.00 & 1.45 & 160586 & 1355 & 15,0586 \\
\hline $\mathrm{N} * 0$ & 1.56 & 0.56 & 023571 & -14 & -0.71429 \\
\hline $\mathrm{K}=0$ & 3.65 & 1.62 & 0.42075 & -2.23 & -0.57822 \\
\hline$v$ & 156 & 99 & 063462 & -57 & -0.36538 \\
\hline $\mathrm{Fe}$ & 2.44 & 2175 & 0.89139 & -0.265 & -0.10861 \\
\hline$c_{u}$ & 17.7 & 41.65 & 255311 & 23.95 & 1.35311 \\
\hline $\mathrm{Za}$ & 48.4 & 39.3 & 0.81191 & 41 & -0.18500 \\
\hline Nu & 0.0009 & 0.0012 & 0.222122 & $-0,0007$ & +07778 \\
\hline $\mathrm{K}$ & 8.23 & 0048 & 0.195652 & 0.159 & -0.00435 \\
\hline$P$ & 19.35 & 18.87 & 2.975194 & 4.48 & -0.00481 \\
\hline$C_{0}$ & 232 & 15.4175 & 0.664507 & $-7,7825$ & -0.33545 \\
\hline 5 & 6.01 & 0.02 & 2 & 0.01 & 1 \\
\hline$a$ & 5.03 & 13.045 & 4348353 & 13015 & 433.8333 \\
\hline 5 & 107 & 15.65 & 0.146262 & .91 .35 & -0.85374 \\
\hline $\mathrm{Ag}$ & 0.105 & 0.9005 & 922816 & 0.8479 & 822316 \\
\hline Sa & i & 29 & 0.025 & -1.5 & -2375 \\
\hline$B a$ & 456 & 20535 & Q 44005 & -260.75 & -0.55585 \\
\hline $\mathrm{No}$ & 123 & 4.45 & $0.351 \% 9$ & -785 & -0.63821 \\
\hline Th & 16.55 & 5.635 & 0.33799 & -11165 & -0.66261 \\
\hline As & 3.23 & 355 & 10900 & 0.32 & $0.0990 ?$ \\
\hline 0 & 4.II & 1359 & 0.32968 & -2795 & -0.67012 \\
\hline
\end{tabular}

\section{Perubahan Komposisi Oksida/Unsur pada Alterasi Serisitik}

Alterasi serisitik dicirikan oleh kehadiran mineral serisit dan atau muskovit, klorit, mineral opak dan kuarsa. Pada alterasi ini, oksida/unsur yang immobile adalah $\mathrm{Hf}, \mathrm{Lu}, \mathrm{Yb}, \mathrm{Ho}$, Er, Tb, Tm dan $\mathrm{TiO}_{2}(\mathrm{Gambar}$ 4). Oksida/unsur yang mengalami penambahan adalah $\mathrm{Sb}, \mathrm{Zr}, \mathrm{Ag}, \mathrm{Pb}, \mathrm{K}, \mathrm{Na}_{2} \mathrm{O}$ dan $\mathrm{SiO}_{2}$ (Tabel 2). Oksida/unsur yang berkurang adalah $\mathrm{U}, \mathrm{Th}, \mathrm{Co}$, As, $\mathrm{Nb}, \mathrm{Ba}, \mathrm{Sn}, \mathrm{Sr}, \mathrm{Ca}, \mathrm{S}, \mathrm{Au}, \mathrm{V}, \mathrm{Zn}, \mathrm{Cu}, \mathrm{Fe}, \mathrm{K}_{2} \mathrm{O}, \mathrm{MnO}$, $\mathrm{CaO}, \mathrm{MgO}, \mathrm{Fe}_{2} \mathrm{O}_{3}$. Pada alterasi serisit ini, terjadi peningkatan nilai $\mathrm{K}$ (kalium) karena plagioklas telah berubah menjadi serisit. Pengurangan oksida pada $\mathrm{CaO}$ yang tidak signifikan pada kondisi ini merupakan akibat proses peluruhan mineral plagioklas menjadi mineral serisit yang mulai tampak. Oksida $\mathrm{SiO}_{2}$ yang bertambah diakibatkan oleh proses pembentukan urat-urat kuarsa yang mulai berkembang. Peningkatan oksida $\mathrm{Na}_{2} \mathrm{O}$ mencerminkan proses penggantian $\mathrm{Na}$ pada plagioklas atau sebagai penanda kehadiran $\mathrm{Na}$ yang menggantikan plagioklas. Bertambahnya unsur $\mathrm{Sb}$ kemungkinan berhubungan dengan kehadiran mineral stibnit yang bersesuaian dengan kadar mineral bijih (Hasria dkk., 2017; Hasria dkk., 2019a). Adapun penambahan unsur $\mathrm{Au}$ (emas) pada alterasi ini diindikasikan karena alterasi ini umumnya berasosiasi dengan batas urat yang sejajar dan memotong bidang foliasi yang menunjukkan bahwa pembentukan alterasi ini merupakan fase awal pengayaan endapan emas di daerah penelitian. Pendekatan ini didasarkan keterdapatan mineral pada zona urat yang dianggap sebagai jalur keluarnya fluida hidrotermal yang menyebabkan batuan memberi respon terhadap fluida, sehingga terjadinya perubahan mineral dan pengendapan mineral hidrotermal yang baru. Kehadiran kuarsa yang sejajar dan memotong bidang foliasi mengindikasikan adanya pengaruh struktur terhadap proses alterasi.

Alterasi ini tersebar pada bagian utara, tenggara dan pada bagian selatan daerah penelitian. Pada bagian utara memiliki orientasi sebaran yang menerus dengan arah relatif barat-timur dan pada bagian tenggara memiliki sebaran yang memanjang dengan arah relatif baratdaya-timurlaut. Pada bagian selatan tersebar secara spot-spot atau setempat-setempat. Keberadaan alterasi ini berasosiasi terhadap struktur geologi berupa sesar yang berarah timurlaut - baratdaya (Gambar 5).

Pada alterasi ini, kuarsa sekunder hadir melimpah dan mengisi urat pada foliasi batuan metamorf. Klorit umumnya hadir sebagai mineral primer, sedangkan mineral opak hadir merata sebagai inklusi di antara kuarsa sekunder dan erat kaitannya dengan mineralisasi. Mineral opak pada alterasi ini terbentuk bersamaan dengan proses pengendapan fluida yang memungkinkan terjadinya fase mineralisasi. Berdasarkan kehadiran mineral pada alterasi ini, maka alterasi hidrotermal pada zona ini diperkirakan terbentuk pada temperatur antara 200-280 ${ }^{\circ} \mathrm{C}$ (Hedenquist dkk., 2000; Corbett dan Leach, 1997 .

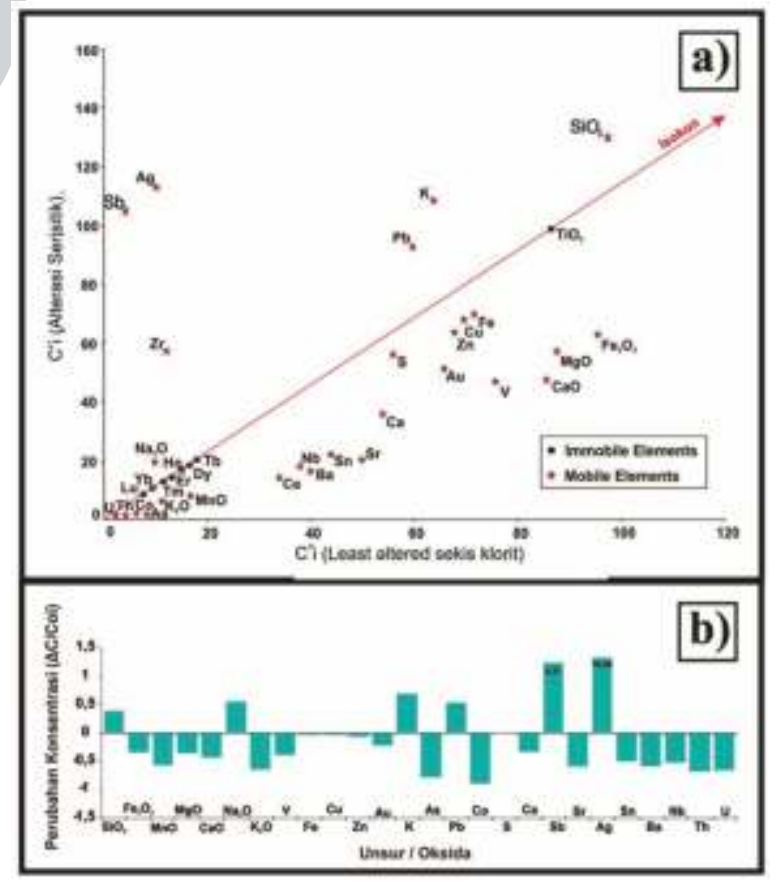

Gambar 4. Ploting antara least altered dengan alterasi serisitik batuan sekis klorit. a). diagram isokon, b). Perubahan konsentrasi (? C/ Coi) antara least alter ed dan alterasi serisitik pada batuan sekis klorit. Oksida dan unsur $\mathrm{Ca}$, $\mathrm{Fe}$, $\mathrm{K}$ dan Sdalamwt. \%dan unsur lainnyadalamppm. 
Tabel 2. Analisis isokon pada alterasi serisitik Pegunungan Rumbia

\begin{tabular}{|c|c|c|c|c|c|}
\hline $\begin{array}{l}\text { Unuar } \\
\text { okvida }\end{array}$ & $\begin{array}{c}\text { Sampel } \\
\text { least } \\
\text { alturnd }\end{array}$ & $\begin{array}{l}\text { Rerata } \\
\text { samaped } \\
\text { bahuaa } \\
\text { teralterasi }\end{array}$ & $\begin{array}{c}\text { Slepe titik } \\
\text { data }\end{array}$ & 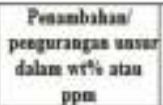 & 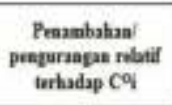 \\
\hline & $\mathrm{CO}$ & $\mathrm{CH}_{4}$ & $\mathrm{CASO}_{3}$ & $B C$ & $\mathrm{SCiCO}$ \\
\hline $\mathrm{SO}_{2}$ & 50 & 701 & 1402 & 20.1 & $8+402$ \\
\hline $\mathrm{FeOH}_{1}$ & 929 & 61 & 665662 & -3.19 & 70.3933 \\
\hline $\mathrm{MaO}$ & 2.14 & 006 & 0428571 & 0.08. & 0.57143 \\
\hline $\mathrm{M}_{2} \mathrm{O}$ & 169 & 11 & 0.650188 & -6.59 & -0.34911 \\
\hline$C 0$ & 069 & 0.05 & 0555556 & Q64 & $-0+4144$ \\
\hline $\mathrm{NaO}$ & 1.96 & 3.08 & 1.57143 & 1.12 & 0.57143 \\
\hline $\bar{K}, 0$ & 3.85 & 137 & 0.35584 & 2.48 & 0.6416 \\
\hline v & 156 & 96 & 0.61578 & 60 & 0.38462 \\
\hline $\mathrm{Fe}$ & 244 & 236 & 0967213 & 608 & 0.03279 \\
\hline $\mathrm{Cu}$ & 127 & 1715 & 0965927 & $A 53$ & -0.03107 \\
\hline At & 0000 & 0.6007 & 0.7778 & $\$ .0021$ & -0.2222 \\
\hline K & 0.23 & 039 & 1653652 & 0.16 & 0.695652 \\
\hline As & 3.23 & 0.69 & 0.213622 & 2.54 & 4.78694 \\
\hline$\overline{P B}$ & 1935 & 29,9 & 1.54522 & 10.55 & 0.5552 \\
\hline$C_{0}$ & 232 & 2.48 & 0.10639 ? & 30.72 & 08931 \\
\hline 5 & 001 & 001 & 1 & 0 & 0 \\
\hline$C_{2}$ & 0.03 & 0.02 & 0.666667 & 0.01 & 833333 \\
\hline 56 & 0.733 & 389 & 5300068 & 3157 & 430658 \\
\hline$Z_{n}$ & 484 & 452 & 695388 & .32 & -0.06512 \\
\hline 5 & 107 & 435 & 0466542 & -635 & -0.59346 \\
\hline As & 0.103 & 117 & 11.19922 & 1057 & 1035922 \\
\hline Sa & 4 & 2 & 0.5 & 2 & 0.5 \\
\hline $\bar{B}$ & 466 & 1905 & 0.528 & 2755 & 05912 \\
\hline$\overline{\mathrm{Nb}}$ & 123 & 5.9 & 0.47967 & 64 & 4520033 \\
\hline Th & 16.85 & 529 & 0.31395 & 1156 & 0.63505 \\
\hline t & 411 & 141 & 0.34307 & 7.7 & 665 \\
\hline
\end{tabular}

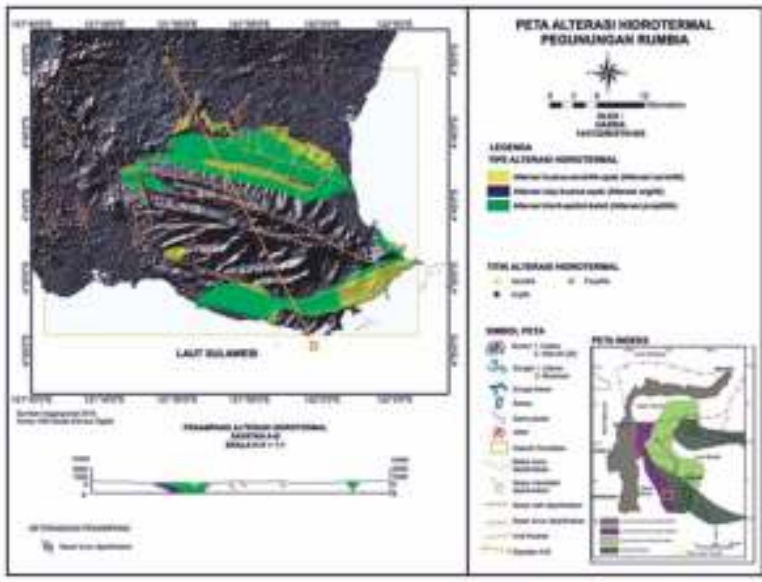

G ambar 5. Peta alterasi daerah penelitian.

\section{Perubahan Komposisi Oksida/Unsur pada Alterasi Argilik}

Alterasi argilik dicirikan oleh kehadiran mineral lempung dan kuarsa serta mineral opak. Oksida/unsur yang cenderung immobile pada alterasi ini adalah $\mathrm{Hf}$, $\mathrm{Lu}, \mathrm{Yb}, \mathrm{Tm}, \mathrm{Ho}, \mathrm{Tb}, \mathrm{Er}$ dan $\mathrm{TiO}_{2}$ (Gambar 4). Adapun oksida/unsur yang mengalami penambahan adalah $\mathrm{Sb}, \mathrm{Fe}, \mathrm{S}, \mathrm{Cu}, \mathrm{Zr}, \mathrm{Ba}, \mathrm{As}, \mathrm{Au}, \mathrm{Zn}, \mathrm{V}$, dan $\mathrm{SiO}_{2}$ Oksida/unsur yang cenderung mengalami pengurangan adalah $\mathrm{Ca}, \mathrm{U}, \mathrm{Th}, \mathrm{Nb}, \mathrm{Sn}, \mathrm{Sr}, \mathrm{Co}, \mathrm{Pb}, \mathrm{K}$, $\mathrm{CaO}, \mathrm{Na}_{2} \mathrm{O}, \mathrm{MnO}, \mathrm{MgO}, \mathrm{K}_{2} \mathrm{O}$ dan $\mathrm{Fe}_{2} \mathrm{O}_{3}$ (Tabel 3). Oksida $\mathrm{Fe}_{2} \mathrm{O}_{3}$ mengalami pengurangan konsentrasi yang disebabkan oleh pembentukan mineral hematit pada alterasi masih minor dan pembentukan mineral pirit dan kalkopirit yang masih dominan. Hal ini didukung oleh peningkatan unsur $\mathrm{Cu}, \mathrm{Fe}$ dan $\mathrm{S}$. Pengurangan konsentrasi oksida $\mathrm{Na}_{2} \mathrm{O}, \mathrm{K}_{2} \mathrm{O}$ dan unsur Sr disebabkan karena perusakan (breakdown) mineral plagioklas dalam batuan, serta ketidakhadiran biotit sekunder. Oksida $\mathrm{SiO}_{2}$ juga mengalami peningkatan konsentrasi meskipun tidak begitu signifikan. Hal ini bersesuaian dengan zonasi alterasi, yakni semakin ke arah dalam (pusat), maka akan terjadi penambahan unsur Si. Unsur $\mathrm{Ba}$ dan $\mathrm{Sr}$ mengalami pengurangan konsentrasi menunjukkan terjadinya perusakan (breakdown) yang terjadi pada mineral plagioklas. Penambahan unsur $\mathrm{Au}, \mathrm{Cu}, \mathrm{Fe}, \mathrm{Sb}$ dan $\mathrm{S}$ diinterpretasikan berhubungan dengan kehadiran mineral bijih emas ( $\mathrm{Au})$, pirit $(\mathrm{FeS})$, kalkopirit $\left(\mathrm{CuFeS}_{2}\right)$ dan stibnit $\left(\mathrm{Sb}_{2} \mathrm{~S}_{3}\right.$; Hasria dkk., 2017). Peningkatan unsur As di daerah penelitian diindikasikan berkaitan dengan kehadiran mineral arsenopirit $\left(\mathrm{FeAsS}_{2}\right.$; Idrus dkk., 2012). Peningkatan unsur-unsur tersebut bersesuaian dengan hasil analisis mikroskopis bijih dan geokimia bijih FA/AAS AAS (Fire Assay/Atomic Absorption Spektrophotometry) yang dilakukan oleh Hasria dkk. 2017) dan Hasria dkk. (2019a). Analisis mikroskopis bijih dan geokimia bijih FA/AAS juga menunjukkan peningkatan unsur $\mathrm{Hg}$ pada alterasi ini, dicirikan oleh kehadiran mineral sinnabar $(\mathrm{HgS})$ yang melimpah di daerah penelitian. Unsur Au (emas) pada alterasi ini menunjukkan peningkatan hingga 18 ppm.

Paragenesa alterasi ini berasosiasi terhadap batas urat, mengindikasikan bahwa alterasi ini terbentuk setelah pengendapan fluida hidrotermal pada urat. Dengan demikian, pada alterasi ini terjadi pengkayaan endapan emas. Penyebaran alterasi ini ditemukan di bagian utara daerah penelitian yang berasosiasi dengan struktur sesar, sedangkan di bagian barat diidentifikasikan struktur minor seperti kekar yang mengontrol keberadaan alterasi (Gambar 6). Sebaran alterasi ini di daerah penelitian cenderung tidak luas, akan tetapi hubungannya dengan mineralisasi sangat besar. Berdasarkan hasil analisis geokimia bijih menunjukkan bahwa kadar emas tertinggi terdapat pada alterasi ini, yakni 18 ppm. Endapan emas di daerah penelitian berdasarkan karakteristik alterasi dan mineralisasi (Hasria dkk., 2017) dan geokimia (Hasria dkk., 2019a), serta fluida hidrotermal (Hasria dkk., 2019b) diklasifikasikan dalam tipe endapan emas orogenik (Groves dkk., 1998; Goldfarb dkk., 2001; Goldfarb dan Groves, 2015).

Pada alterasi ini, klorit yang hadir bersamaan dengan mineral lempung dan umumnya hadir sebagai mineral primer. Kuarsa sekunder hadir merata berasosiasi dengan mineral lempung yang ditemukan pada batuan metamorf sekis mika, sekis klorit, serpentinit dan batuan teralterasi. Pada fase akhir proses pengendapan fluida sangat memungkinkan terkristalisasinya mineral kuarsa yang berasosiasi dengan keberadaan mineral-mineral lempung. 
Tabel 3. Analisis isokon pada alterasi argilik Pegunungan Rumbia

\begin{tabular}{|c|c|c|c|c|c|}
\hline $\begin{array}{l}\text { Cousur } \\
\text { odsida }\end{array}$ & $\begin{array}{c}\text { Sanopl } \\
\text { leas } \\
\text { altered }\end{array}$ & $\begin{array}{l}\text { Rerata } \\
\text { sampel } \\
\text { batana } \\
\text { teralterail }\end{array}$ & $\begin{array}{c}\text { Slope } \\
\text { tink data }\end{array}$ & 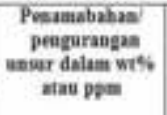 & $\begin{array}{c}\text { Penambahan } \\
\text { peugurangua } \\
\text { relatif terhadap } \\
\text { COS }\end{array}$ \\
\hline & का & $\mathrm{CH}^{4}$ & वालव & $\triangle \mathrm{CI}$ & $\triangle C U C O$ \\
\hline $5 \times 2 !$ & 50 & 588 & 1.176 & 8.8 & 0.176 \\
\hline Fer. & 929 & 9.12 & 0.051701 & -017 & -0.0183 \\
\hline $\mathrm{MEO}$ & 0.14 & 0.02 & 0.142857 & -0.12 & 0.85714 \\
\hline $\mathrm{Mg} \mathrm{O}$ & 169 & 1.22 & 0.721893 & $-0,47$ & -027811 \\
\hline $\mathrm{CaO}$ & 009 & 0.01 & $0.11 t 111$ & -0.08 & 0.88899 \\
\hline $\mathrm{X}_{2} 20$ & 196 & 034 & 0.173459 & -162 & -082653 \\
\hline K20 & 385 & 372 & 0.050234 & -013 & .00377 \\
\hline v & 156 & 161 & 1.032051 & 5 & 0.032051 \\
\hline Fe & 244 & 5.45 & 2337705 & 302 & 12975 \\
\hline $\mathrm{Cu}$ & 17.7 & 619 & 3.497175 & $\mathrm{H}_{2}$ & 2497175 \\
\hline $\mathrm{Zn}$ & 13.9 & 595 & 1.239339 & IIII & 0229339 \\
\hline Af & 0.0009 & 0.0124 & 13.7778 & 0.0115 & 1277778 \\
\hline$\overline{\mathbb{K}}$ & 0.23 & 0.21 & 0.913043 & -0.02 & 0.08696 \\
\hline $\mathrm{Pb}$ & 1635 & III.15 & 0.576227 & 82 & 042377 \\
\hline $\mathrm{Co}$ & 232 & 102 & 0.439655 & -13 & -056034 \\
\hline 5 & 001 & 0.05 & 3 & 0.2 & \\
\hline$a$ & 0.03 & 0.01 & 0.333333 & $-0,02$ & -066607 \\
\hline 58 & 107 & 227 & 021215 & -843 & 0.78735 \\
\hline$A g$ & 0.103 & 0.104 & 1009709 & 0.001 & 0.009709 \\
\hline Sa & (3) & 3 & 075 & -1 & .025 \\
\hline Ga & 466 & 555 & $1.15005 ?$ & 39 & 0.190537 \\
\hline $\mathrm{N}$ & 123 & 121 & 1.04085 & 0.5 & 004065 \\
\hline $\bar{n}$ & 1635 & 10.35 & $0.6370 \mathrm{~B}$ & -61 & $636: 12$ \\
\hline As & 3.23 & 49.1 & 15,20124 & 8587 & $1+21024$ \\
\hline E & 411 & 121 & 0.34404 & .29 & .0 .7056 \\
\hline
\end{tabular}

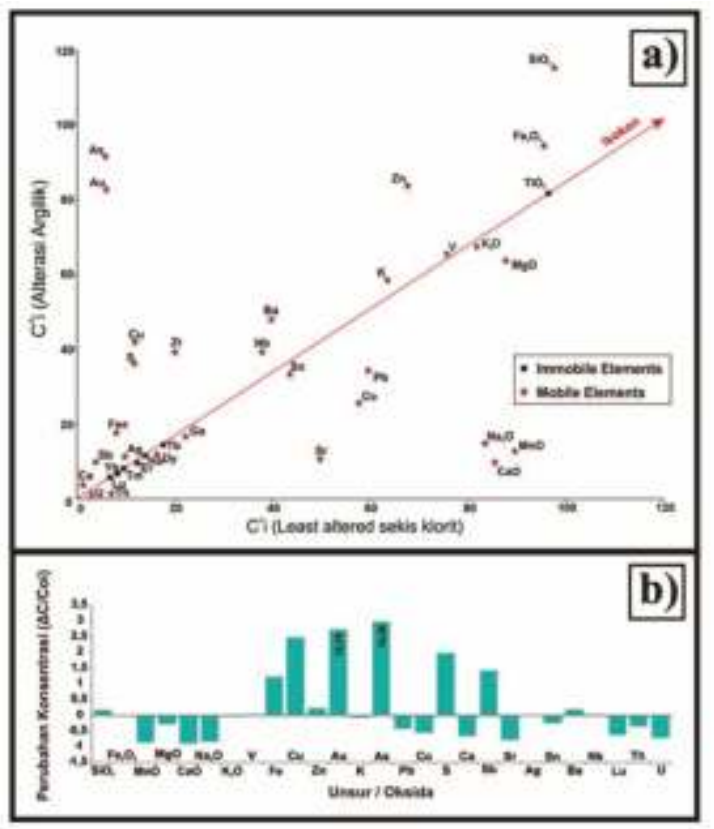

G ambar 6. Ploting antara least alter ed dengan alterasi argilik batuan sekis klorit. a). diagram isokon, b). Perubahan konsentrasi (?C/ Coi) antara least altered dan alterasi argilik pada batuan sekis klorit. Senyawa utama (oksida) dan unsur $\mathrm{Ca}, \mathrm{Fe}, \mathrm{K}$ dan S dalam wt. \% dan unsur lainnya dalam ppm.

Hasil analisis XRD yang dikorelasikan dengan mineral hasil analisis sayatan tipis, diketahui bahwa mineral lempung yang hadir adalah kaolinit dan illit (a). Kaolinit dan illit merupakan kelompok mineral lempung yang hadir sebagai masa dasar, serta umumnya hadir pada sekis klorit, sekis mika, serpentinit dan batuan alterasi. Keberadaan mineral lempung ini merupakan hasil alterasi dari mineral feldspar seperti plagioklas. Berdasarkan kehadiran mineral kuarsa, kaolinit, illit dan klorit, maka pembentukan dari alterasi ini diperkirakan berada pada temperatur $200-300^{\circ} \mathrm{C}$ (Hedenquist dkk., 2000; Corbett dan Leach, 1997).

\section{Geokimia REE pada Batuan Sekis Klorit Pegunungan Rumbia}

Studi tentang distribusi REE (Rare Earth Elements) pada zona alterasi dapat memperjelas hubungan antara penambahan dan pengurangan unsur REE pada alterasi batuan samping. Data petrografi menunjukkan bahwa pola unsur REE batuan yang teralterasi didominasi oleh kelimpahan serisit, illit, monmorilonit, kaolinit dan dickit (Schneider dkk., 1988). REE merupakan unsurunsur yang dapat termobilisasi kembali selama terjadinya proses alterasi hidrotermal, khususnya alterasi serisitik, kloritisasi, argilik dan potasik (Alderton dkk., 1980; Poitrasson dkk., 1995; Idrus dkk., 2009). Unsur REE pada umumnya cenderung mengalami pengurangan/deplesi seiring meningkatnya intensitas alterasi. Hal ini disebabkan karena fluida hidrotermal yang melewati batuan dinding dapat meremobilisasi unsur-unsur REE yang dilaluinya. Apabila alterasi hidrotermal terjadi, maka terjadi perubahan ph, Eh dan kesetimbangan komposisi antara batuan dan fluida sehingga terjadi mobilisasi REE. Mobilitas unsur dalam cairan hidrotermal dikendalikan oleh temperatur, tekanan dan sifat kimia larutan hidrotermal ( $\mathrm{pH}$ dan Eh; Van Dongen dkk., 2010).

Diagram REE normalisasi chondrite menggunakan sampel yang sama, yakni batuan sekis klorit pada alterasi propilitik, serisitik dan alterasi argilik, digunakan untuk menentukan penambahan dan pengurangan unsur REE dalam satu jenis batuan berdasarkan hasil analisis ICPAES dan ICP-MS. Analisis geokimia menggunakan REE chondrite di Pegunungan Rumbia berdasarkan nilai unsur REE umumnya cenderung menurun/berkurang seiring dengan meningkatnya intensitas alterasi yang dimulai dari alterasi propilitik, kemudian alterasi serisitik dan terakhir adalah alterasi argilik (Gambar 7).

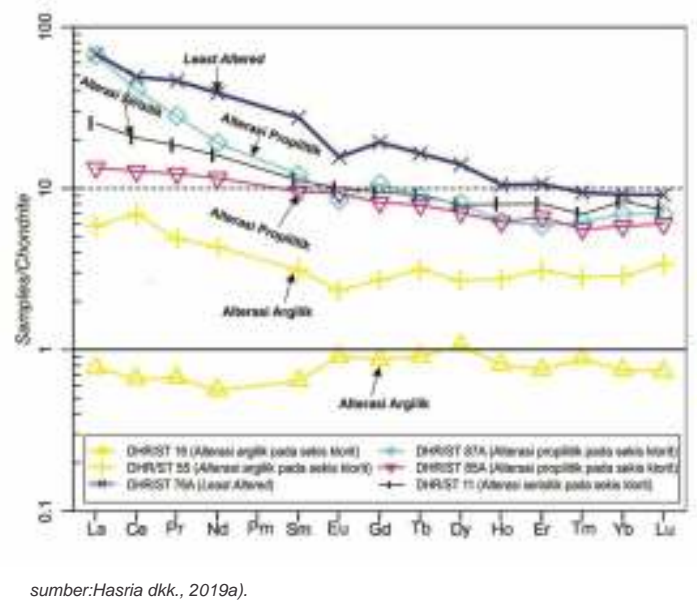

Gambar 7. Ploting data unsur REE pada diagram REE N ormalisasi Chondrite (Sun dan McDonough, 1995) pada batuan sekis klorit dengan beberapazonaalterasi di Pegunungan Rumbia. 
Pada alterasi propilitik, tingkatan alterasi yang terjadi pada zona ini umumnya relatif lemah (least altered), yakni $<25 \%$ komposisi batuan asal, dicirikan dengan mineral plagioklas yang belum teralterasi hingga sedang (selectively pervasive). Alterasi hanya terjadi pada mineral-mineral tertentu pada batuan metamorf, misalnya klorit hanya mengganti mineral mafik saja. Dengan demikian, pada alterasi ini unsur REE belum banyak yang mengalami remobilisasi. Adapun alterasi serisitik pada umumnya memiliki intensitas alterasi sedang (selective pervasive) dimana $25-75 \%$ komposisi batuan asal tergantikan oleh mineral hidrotermal, misalnya mineral serisit menggantikan mineral plagioklas. Pada alterasi ini, unsur REE sudah mengalami deplesi akibat alterasi yang terjadi. Pada alterasi argilik, intensitas alterasi pada umumnya kuat (pervasive) dimana $>75 \%$ komposisi mineral asal tergantikan menjadi mineral-mineral baru. Alterasi ini dicirikan oleh pembentukan mineral lempung yang menggantikan plagioklas dan mineral-mineral silikat mafik seperti hornblende (Hasria dkk., 2019a; Pirajno, 2009). Unsur REE yang menurun/berkurang seiring meningkatnya intensitas alterasi di daerah penelitian pada umumnya berhubungan dengan perubahan komposisi mineral setelah proses alterasi hidrotermal akibat fluida hidrotermal yang melewati batuan.

\section{KESIMPULAN}

Pada alterasi propilitik, oksida/unsur yang cenderung immobile adalah $\mathrm{Hf}, \mathrm{Lu}, \mathrm{Yb}, \mathrm{Tm}, \mathrm{Ho}, \mathrm{Tb}, \mathrm{Er}$ dan $\mathrm{TiO}_{2}$. Adapun oksida/unsur mobile yang mengalami penambahan adalah $\mathrm{As}, \mathrm{Zr}, \mathrm{Cu}, \mathrm{Sb}, \mathrm{Ca}, \mathrm{CaO}, \mathrm{MgO}$, $\mathrm{MnO}$ dan $\mathrm{SiO}_{2}$ dan oksida/unsur yang mengalami pengurangan adalah $\mathrm{U}, \mathrm{Th}, \mathrm{Co}, \mathrm{Sn}, \mathrm{Sr}, \mathrm{Nb}, \mathrm{Ba}, \mathrm{K}, \mathrm{Au}$, $\mathrm{Pb}, \mathrm{Zn}, \mathrm{V}, \mathrm{Fe}, \mathrm{K}_{2} \mathrm{O}, \mathrm{Na}_{2} \mathrm{O}$ dan $\mathrm{Fe}_{2} \mathrm{O}_{3}$. Pada alterasi serisitik, oksida/unsur yang immobile adalah $\mathrm{Hf}, \mathrm{Lu}$, $\mathrm{Yb}, \mathrm{Ho}, \mathrm{Er}, \mathrm{Tb}, \mathrm{Tm}, \mathrm{TiO}_{2}$, sedangkan oksida/unsur mobile yang mengalami penambahan adalah $\mathrm{Sb}, \mathrm{Zr}$, $\mathrm{Ag}, \mathrm{Pb}, \mathrm{K}, \mathrm{Na}_{2} \mathrm{O}, \mathrm{SiO}_{2}$ dan yang mengalami pengurangan adalah $\mathrm{U}, \mathrm{Th}, \mathrm{Co}, \mathrm{As}, \mathrm{Nb}, \mathrm{Ba}, \mathrm{Sn}, \mathrm{Sr}, \mathrm{Ca}$, $\mathrm{S}, \mathrm{Au}, \mathrm{V}, \mathrm{Zn}, \mathrm{Cu}, \mathrm{Fe}, \mathrm{K}_{2} \mathrm{O}, \mathrm{MnO}, \mathrm{CaO}, \mathrm{MgO}, \mathrm{Fe}_{2} \mathrm{O}_{3}$. Pada alterasi argilik, oksida/unsur yang cenderung immobile adalah $\mathrm{Hf}, \mathrm{Lu}, \mathrm{Yb}, \mathrm{Tm}, \mathrm{Ho}, \mathrm{Tb}, \mathrm{Er} \mathrm{dan}_{\mathrm{TiO}_{2}}$.
Adapun oksida/unsur yang mengalami penambahan adalah $\mathrm{Sb}, \mathrm{Fe}, \mathrm{S}, \mathrm{Cu}, \mathrm{Zr}, \mathrm{Ba}, \mathrm{As}, \mathrm{Au}, \mathrm{Zn}, \mathrm{V}$, dan $\mathrm{SiO}_{2}$ sedangkan oksida/unsur yang cenderung mengalami pengurangan adalah $\mathrm{Ca}, \mathrm{U}, \mathrm{Th}, \mathrm{Nb}, \mathrm{Sn}, \mathrm{Sr}, \mathrm{Co}, \mathrm{Pb}, \mathrm{K}$, $\mathrm{CaO}, \mathrm{Na}_{2} \mathrm{O}, \mathrm{MnO}, \mathrm{MgO}, \mathrm{K}_{2} \mathrm{O}$ dan $\mathrm{Fe}_{2} \mathrm{O}_{3}$.

Unsur REE yang menurun/berkurang seiring meningkatnya intensitas alterasi di daerah penelitian pada umumnya berhubungan dengan perubahan komposisi mineral setelah proses alterasi hidrotermal berlangsung akibat fluida hidrotermal yang melewati batuan.

Berdasarkan hasil interpretasi tersebut terlihat bahwa kehadiran emas di daerah penelitian terdapat pada alterasi propilitik, serisitik dan alterasi argilik. Namun demikian, pada alterasi argilik memiliki kandungan emas yang lebih tinggi dibandingkan alterasi lainnya. Berdasarkan karakteristik alterasi dan mineralisasi, geokimia dan fluida hidrotermal menunjukkan bahwa endapan emas di daerah penelitian diklasifikasikan ke dalam tipe endapan emas orogenik yang dapat menjadi target baru eksplorasi endapan emas di Sulawesi Tenggara khusunya dan Indonesia pada umumnya.

\section{UCAPAN TERIMAKASIH}

Terimakasih kami sampaikan kepada Kemristekdikti dalam pendanaan penelitian ini baik dalam bentuk beasiswa BPPDN (Beasiswa Program Pascasarjana Dalam Negeri) maupun bantuan penelitian Disertasi Doktor. Terimakasih juga kami sampaikan kepada Dinas Pertambangan Sulawesi Tenggara karena telah memberikan izin penelitian di Pegunungan Rumbia, Bombana. Terimakasih kepada PT. Panca Logam Makmur (PLM) atas bantuan fasilitas dalam pengambilan sampel di lapangan. Terimakasih kepada Laboratorium ALS Canada atas analisis sampel ICPAES dan ICP-MS. Terimaksih kepada mahasiswa Teknik Geologi Universitas Halu Oleo yang telah ikut membantu pengambilan sampel di lapangan. Ucapan terimaksih juga kami sampaikan kepada Bapak Dr. La Ode Ngkoimani, S.Pd., M.Si. atas bantuan fasilitas dalam pengambilan sampel di lapangan.

\section{ACUAN}

Alderton, D.H.M., Pearce, J.A., and Potts, P.J., 1980. Rare Earth Element Mobility During Granite Alteration. Earth Planet. Science Letters, 49: 149-165.

Canada, A.G., 2018. Services \& Fees Schedule of. alsglobal.com/geochemistry, Canada.

Corbett, G. and Leach, T., 1997. Gold-Copper Systems? Structure, Alteration, and Mineralization. Corbett Geological Servicse 29 Carr Street North Sydney NSW 2060 Australia and Terry Leach and Co Coromandel New Zealand, Australia and New Zealand. 
Goldfarb, R.J. and Groves, D.I., 2015. Orogenic Gold: Common or Evolving Fluid and Metal Sources Through Time. Lithos, 233:2-26.

Goldfarb, R.J., Groves, D.I. and Gardoll, S., 2001. Orogenic Gold and Geologic Time? A Global Synthesis. Ore Geology Reviews, 18: 1-75.

Grant, J.A., 2005. Isocon Analysis: A Brief Review of the Method and Applications. Physics Chemistry Earth, 30: 997-1004.

Grant, J.A., 1986. The Isocon Diagram - A Simple Solution to Gresens' Equation for Metasomatic Alteration. Economic Geology, 81: 1976-1982.

Gresens, R.L., 1967. Composition-Volume Relationships of Metasomatism. Chemistry Geology, 2: 47-65.

Groves, D.I., Goldfarb, R.J., Gebre-Mariam, M., Hagemann, S.G. and Robert, F., 1998. Orogenic Gold Deposits: A Proposed Classification in the Context of Their Crustal Distribution and Relationship to Other Gold Deposit Types. Ore Geology Reviews, 13: 7-27.

Hasria., Idrus, A., Warmada, I.W., 2019a. Alteration, Mineralization and Geochemistry of Metamorphic Rocks Hosted Hydrothermal Gold Deposit at Rumbia Mountains, Bombana Regency, Southeast Sulawesi, Indonesia. Journal of Geoscience Engineering Environment and Technology, 04: 83-92.

Hasria., Idrus, A., Warmada, I.W., 2019b. Karakteristik Fluida Hidrotermal Endapan Emas Orogenik di Pegunungan Rumbia, Kabupaten Bombana, Provinsi Sulawesi Tenggara. Jurnal Geologi dan Sumberdaya Mineral, 20: 111117.

Hasria., Idrus, A., Warmada, I.W., 2017. The Metamorphic Rocks-Hosted Gold Mineralization At Rumbia Mountains Prospect Area In The Southeastern Arm Of Sulawesi Island, Indonesia. Journal of Geoscience Engineering Environment and Technology, 2: 217-223.

Hedenquist, J.W., R, A.A., Gonzalez-Urien, E., 2000. Hedenquist Arribas Gonzalez-Urien 2000. Economic Geology, 13: 245-277.

Idrus, A., Kolb, J. and Meyer, F.M., 2009. Mineralogy, lithogeochemistry and Elemental Mass Balance of the Hydrothermal Alteration Associated with the Gold-rich Batu Hijau Porphyry Copper Deposit, Sumbawa Island, Indonesia. Resources Geology, 59:215-230.

Idrus, A., Prihatmoko, S., Warmada, I.W., Nur, I., Meyer, F.M., 2012. The Metamorphic Rock-Hosted Gold Mineralization at Bombana, Southeast Sulawesi: A New Exploration Target in Indonesia. Resources Geology, 22, $35-48$.

Permana, H., 2013. Kompleks Batuan Malihan, in: Surono, Udi Hartono (Eds.), Geologi Sulawesi. Bandung, pp. $127-152$.

Pirajno, F., 2009. Hydrothermal Processes and Mineral System. Springer, Australia.

Poitrasson, F., Pin, C. and Duthou, J.L., 1995. Hydrothermal Remobilization of Rare Earth Elements and Its Effect on Nd Isotopes in Rhyolite and Granite. Earth Planetary Science Letters, 130: 1-11.

Schneider, H.J., Ozgur, N. and Palacios, C.M., 1988. Relationship Between Alteration, Rare Earth Element Distribution, and Mineralization of the Murgul Copper Deposit, Northeastern Turkey. Economic Geology, 83: 1238-1246.

Simandjuntak, T.O., Surono, Sukido, 1993. Peta Geologi Lembar Kolaka, Sulawesi, Skala 1:250.000. Pusat Penelitian dan Pengembangan Geologi, Bandung.

Surono, 2013. Geologi Lengan Tenggara Sulawesi. Badan Geologi, Kementerian Energi dan Sumber Daya Mineral.

Van Dongen, M., Weinberg, R.F. and Tomkins, A.G., 2010. REE-Y, Ti, and P Remobilization in Magmatic Rocks by Hydrothermal Alteration during Cu-Au Deposit Formation. Economic Geology, 105: 763-776. 